\title{
AS MÍDIAS DIGITAIS COMO FERRAMENTA DE ENSINO E APRENDIZAGEM É POSSÍVEL?
}

\author{
Ana Paula Batista Paro1 \\ Daniele Maria de Oliveira Florêncio² \\ Vanessa da Paixão ${ }^{3}$ \\ Paula Rocha ${ }^{4}$ \\ Juliane Rocha de Moraes ${ }^{5}$
}

Resumo: O presente artigo tem como objetivo refletir sobre a utilização das novas tecnologias pedagógicas na sala de aula promovendo uma discussão sobre a real importância da aplicação da mesma para uma diversificação das atividades educativas, levando, por consequência a uma diversificação da ação pedagógica. Daí a necessidade da inovação na rotina escolar, pois os alunos desta última década são os chamados nativos digitais. Sendo importante também a reflexão dos professores para a elaboração de "plano de mídias", para a definição do plano de aula no uso das mídias digitais na instituição educacional. O professor que resolve modificar seus métodos de ensino, é uma pessoa que compreende o valor e a necessidade de constante inovação na escola.

Pois cada vez mais dependemos das mídias digitais para nossas funções cotidianas, que já estão presentes em todas as áreas da nossa vida social. Claro que nem sempre as mesmas estão disponíveis à todos. Contudo o professor deve estimular os alunos a usarem canais diversos de informação e aprendizagem, além de escutá-lo, contribuindo assim para enriquecer seu próprio repertório de meios e melhor prepará-lo para aprender e aprender, formando e construindo assim, cidadãos questionadores, críticos e principalmente pensadores.

Palavras-chave: Alunos; Aprendizagem; Digitais; Mídias; Professor.

\footnotetext{
1 Pós-Graduação/Inesp, Brasil. E-mail: paulinha_paro@hotmail.com.

2 Pós-Graduação/Inesp, Brasil. E-mail: danieleoliveira131@gmail.com.

3 Pós-Graduação/Inesp, Brasil. E-mail: vanessal1809@hotmail.com.

${ }^{4}$ Pós-Graduação/Inesp, Brasil. E-mail: aluap_123@hotmail.com.

5 Pós-Graduação/Inesp, Brasil. E-mail: juli04.rocha@gmail.com.
} 